811.163.41'373.231

811.163.41'366.52

811.163.41:305-055.2

https://doi.org/10.18485/mks_srpska_slavistika.2018.1.ch20

\author{
Јованка Ј. РАДИЋ* \\ Институт за српски језик САНУ \\ Београд
}

\title{
СРПСКА ЛИЧНА ИМЕНА И ФЕМИНИСТИЧКИ ПОГЛЕДИ НА ЈЕЗИК ${ }^{* *}$
}

\begin{abstract}
У раду се испитује принцип поларизације и начин организација личних имена (ЛИ) у српском језику, првенствено однос између пола, као условно казано семантичке разлике 'женско' - 'мушко', и рода као формалнограматичке карактеристике српских ЛИ - све с циљем да се испита ваљаност феминистичких погледа на језик. Три су основна налаза: (а) подела ЛИ на мушка и женска не почива на формалним карактеристикама (роду) ЛИ као речи, већ на полу као унапред датој разлици која је учитана (/ учитава се) у ЛИ; (б) исти вредносни ранг опозита 'женско' - 'мушко' у ЛИ онемогућава системску организацију и условљава издвојеност ЛИ из језика као система (/ замењивост комплетних именослова без последица по језик); (3) опозитни односи тога типа нису спојиви с организационим начелима језика као система. С тих се полазишта оцењује вештачки модел „родно диференцирног језика”, кога тоталитарним методама у многим језицима инсталирају идеолози или следбеници „родног феминизма”.

Кључне речи: ономастика, антропонимија, лична имена, разлика 'мушко' - 'женско', граматички род, моција рода, феминизам.
\end{abstract}

1. Кад се приступа личним именима (ЛИ), потребно је имати у виду да је све што стоји у вези с њима унапред категорисано и одређено: унапред (аутоматски) се зна да је субјекат ЛИ људско биће, а по себи се зна да су то непоновљиво особене јединке. То „знање” налаже да се у тренутку именовања субјекат ЛИ посматра као „тело и твар” (мушко или женско) која ће се развити у јединствено бивство - жену или „човека”. ${ }^{1}$ ЛИ су стога и стварана и надевана као израз пожељних особина, обично моралних врлина и постигнућа која се „задају” субјекту именовања

\footnotetext{
*jovanka.radic@gmail.com

${ }^{* *}$ Рад је резултат истраживања на пројекту бр. 178030, који финансира Министарство просвете, науке и технолошког развоја Републике Србије.

1 Због ограничења у обиму, овде се износе основне истраживачке смернице и налази, а потпунији увиди у проблеме које је отварала ова тема изложени су у раду под насловом „Шта лична имена говоре о разлици 'мушко' - 'женско', роду и структурној организацији језика” (Ономатолошки прилози XXIV, у штампи).
} 
(Милорад, Миодраг, Милобрат, Миливој(е), Милица, Војслав, Чедомил), и/или као израз пожељног односа других људи и сила добра према особи која ће израсти из новорођеног детета (уп. Братомил, Дедомил, Људмил, Србимил; Богомил, Богумил, Сретомил, Петромил). ${ }^{2}$ Дакле, улога ЛИ је да именујући класира лице као лице ('мушко' или 'женско' дете), а првобитно и да снагом свога значења учини да оно стаса у особу која ће сопствено ЛИ носити као стварну одредбу. Тај начин именовања подразумева утврђен чин, колективу познатог именоватеља, интенцију и изразито чврсту везу између речи (ЛИ) и „ствари” (субјекат ЛИ). ${ }^{3}$ Будући да се тако не именује и не поима ништа друго у физичком и метафизичком свету, нужно је претпоставити да су сва средства од којих су грађена ЛИ, и семантичка и творбено-граматичка (уп. структуру ЛИ Вук, Вука, Вук(о)ман, Вук(о)мир, Вукадин, Вукосав, Вукосава, Вукоје, Вукола, Вукища, Вучица и др.), у састав тих речи улазила с нарочитим функцијама.

1.1. Да би се испитао однос између пола субјеката ЛИ и формалних карактеристика ЛИ као речи, довољно је пажљиво се загледати у тек неколике десетине српских мушких и женских ЛИ изведених од различитих придевских (/ „придевски” узетих) основа с кореном Мил- $(\leftarrow$ псл. *milb, ЭССЯ: *milъ(jb)):

мушка ЛИ Мио(Ł*Милъ), Мил-е, Мил-о, Мил-ко, Мил-ика, Мил-ија (Милија), Мил-оје, Мил-оја : женска ЛИ Мил-а, Мил-ка, Мил-ица, Мил-ија (Милија);

м. Милан, Милан-ко, Милан-ица : ж. Милан-а, Милан-ка;

м. Милен, Милен-ко, Милен-ије : ж. Милен-а, Милен-ка, Милен-ија;

м. Милин, Милин-ко : ж. Милин- $а$, Милин-ка;

м. Милун, Милун-ко, Милун-аи : ж. Милун-а, Милун-ка, Милун-ија, Милун-ика, Милун-ица;

м. Милован, Милован-ко : ж. Милован-а, Милован-ка.

м. Милој-а, Милој-е, Милој-ин, Милој-ко, Милој-аи, Милој-ища : ж. Милој-ка, Милој-ла. ${ }^{4}$

1.2. У обликовању наведених ЛИ, као и у обликовању свих других именица као независних (,Предметних”, „самоставних”) речи, учествује (1) сам род (грамеме -ø, $-a,-o /-e)$ као основно обликовно средство, на основу кога се у српском (и не само у српском) језику све именице деле у три рода, конвенционално названа „мушки”, „женски” и „средњи” род (о томе у Радић 2010а), или (2) именички суфикси као везане творбене морфеме које носе и обележје рода. Најпре ћемо се позабавити улогом суфикса који учествују у наведеним ЛИ, а потом систематизовати обележја рода и размотрити питање уклапања поларизоване разлике 'мушко' - 'женско' у род као трочлану граматичку категорију. Да би се то разјаснило, било је неопходно избећи свако мешање рода именица као речи и пола лица као субјеката ЛИ, тј. занемарити све што ЛИ као речима придолази од њихових субјеката.

\footnotetext{
${ }^{2}$ Функцију заштите од сила зла имају тзв. профилактичка ЛИ, надевана с намером да се силе зла одбију тако што ће бити преварене или застрашене (уп. ЛИ Вук, Лав, Јелен-ко - сачињена од јединица које значе не-људска бића, или ЛИ Грдан - којим се носилац ЛИ представља као непожељно биће).

${ }^{3}$ Пракса надевања истих имена људима и животињама код нас је нова, а укорењена је, вероватно, у урбаним условима живота, где се кућни љубимци почињу доживљавати као „,чланови породице”.

${ }^{4}$ Сва ЛИ навођена у овоме раду доноси Речник имена (Стевановић 2014), који прати регистар са преко 33000 имена сабраних из различитих писаних извора.
} 


\section{Именички суфикси у структури ЛИ}

2. У науци се, углавном, сматра да именички суфикси у структуру ЛИ улазе у функцији „експресивне супстантивизације” (тако, нпр., у вези са псл. суф. -ъkъ и -ъka у ЛИ Милко, Milek, Миока, Милка и др.; ЭССЯ: *milъ(jb)), односно, да поједини именички суфикси у српским ЛИ долазе у функцији моције рода (уп. Клајн 2003: 133, 82 и др.). Иако вредности суфикса у ЛИ не могу бити сасвим независне од њихових вредности у језичком систему, мора се поћи од тога да су они ту, у речима твореним ради именовања унапред категорисаних субјеката, морали бити узимани с нарочитим функцијама.

2.1. Кад је реч о именичкој моцији, могућност дејства тог механизма у ЛИ мора се одбацити из простог разлога што се моција рода јавља као пратилац кретања персоналних апелатива по логичким нивоима (в. т. 5.2), а ЛИ образују тзв. индивидуалне појмове, стабилно везане само за најнижи логички ниво. То, међутим, не значи да поједини суфиксни парови у ЛИ не одражавају деобу ЛИ на мушка и женска: у вези с приматом такве (не-моционе) функције појединих „моционих суфиса” стоји Бошковићево запажање (1936: 62) да ни језички однос типа старица - стараи „није израз моционе употребе наставка -ица: он сам [однос] даје наставку -ица моционо значење".

Примера ради, у ЛИ су као пар (обичан, не моциони) засигурно улазили слабо продуктиван суфикс -ко, који гради мушка ЛИ (ређе и друге називе лица, а тек по изузетку и других бића мушког пола, в. Skok: $-k o$ ), и изразито продуктиван суфикс -ка, који гради женска ЛИ (уп. Милко - Милка, Миленко - Миленка, Милинко - Милинка, Милунко - Милунка, Милојко - Милојка, Милованко - Милованка). У другим предметним областима суфикс -ка учествује с више привидно различитих вредности и функција, укључујући и моциону (уп. станар-ка : станар). Свугде се, међутим, као заједника нит препознаје ,јединичост" и слути могућност да је и тај суфикс сводив на функцију класера (о томе у Радић 2014), тј. назнаке да у подлози датог појма стоји предмет (/представа) из класе ,јединично”. стоји у подлози свих суфикса $к$-типа, а да је њихова потоња диференцијација, потпомогнута учешћем ове или оне грамеме и њиховим међусобним разликама (*-ъ $k$, *-ъ $k a,{ }^{*}$-ъ ko), повезана с потоњим класирањима ,јединичних" или ,јединично” узетих предмета из различитих домена. ${ }^{6}$ Судбина суфикса -ко у језичком систему могла је бити предоређена примарним учешћем у домену 'лице' и односом *-ъko: *-ъka као назнаком разлике 'мушко' - 'женско' у ЛИ: важност тог домена и тог односа могли су чинити брану да такав суфикс уђе у друге домене и односе (остао трајно везан за ЛИ и категорију ,људско”).

\footnotetext{
5 Знак (,...”) користимо у функцији постављања разлике између (1) прикривених вредности, које се само подразумевају или и назначавају на не-посредан начин (,биће”, ,,једно”, ,људско”, „мушко - женско” и др.); и (2) вредности што се уобичајено подводе под „значење” ('...'; нпр. човек 'људско биће'), а подразумевају посредовање и својеврсну симболизацију, тј. ментално представљање и поимање (о томе подробније у Радић 2014: 160-162).

“Још је у антици образлагано да ,једно” може бити ,једно по себи” и ,једно” на неки други начин, нпр. као „самоставан” или тек засебно посматран део „квантитета” типа простор, тело, материја, род, врста или сл. (уп. једин-ка, трун-ка: 'труње', слам-ка: 'слама', трав-ка: 'трава', граш-ка - 'грах', алатка : 'алат', али и женка : жена, сељанка : сељак, сељани, те река, рука, мачка, мајка).
} 
2.2. На сасвим другом полу стоје именички суфикси -ица, -ика и -ија, којима су извдена многа женска и мушка ЛИ, уз могућност да се структурно исто име (нпр. Добрица, Милија) надева лицима мушког и женског пола. ${ }^{7}$ Такви примери, уз паралеле типа Милиц̧а (ж.) : Милојица (м.), искључују могућност да је суфикс -ицุа у ЛИ узиман као формални маркер класе 'женско' (уп. старица : старац; краљица : краљ, Гојовица : Гојко, игуманија : игуман, кафецика : кафеџија). Искључена је, наравно, и могућност да је суфикс -ица у структуру ЛИ улазио у функцији класера не-јединичних (квантитативних) предмета, с вредношћу коју је у језичком систему могао развити као опозит суфиксу -ина (в. Радић 2015). Све то вреди, свакако, и за суфиксе -ија (уп. топониме Србија, Шумадија, Борија) и -ика.

Остаје могућност да је вредност суфикса -ица, -ика и -ија у ЛИ усмеравана на значење основинске јединице, отприлике онако како је на основинску јединицу усмерен суфикс -ика у твореницама (углавном фитоними) типа љут-ика, чемер-ика, тамјан-ика, бун-ика, јад-ика, мљеч-ика, зелен-ика и сл., где гради називе јединичних ентитета које карактерише изразит интензитет укуса, мириса, боје или др. У виду имамо могућност да је -ица у ЛИ подразумевало својеврсно „дуљење” значења основинске јединице (уп. хипокористике типа дущица : душа), а -uјa(-uj-, -ој- и сл.) својеврсно ,збирање”, те је, у складу с тиме, Милица могло значити *'/ особа коју ће красити/ изразито велика (,издужена”) милина или милост’, Милија *'/особа у којој ће бити/ „сабрана” милост’, Милојица *'/особа коју ће красити/ сабрана (-ој-) + „издужена”(-ица ) милост’, док је -ика у Милика (мушко ЛИ) и Милуника (женско ЛИ) могло сугерисати ’милост” као доминатно (/ „издужено”) својство субјекта ЛИ.

Ако се термин „експресивна супстантивизација” тако тумачи, као усмереност суфикса на основинску семантичку јединицу (а не на предмет именовања, с функцијом категоризације предмета као предмета, в. Радић 2014), онда би се управо таква функција могла претпоставити за већину суфикса у ЛИ. При том би, наравно, основни правац вредновања био усклађен с основном језичком вредношћу датог суфикса (нпр. Мил-ка је могло бити творено као *'жена једна (/ прва) у милости', Мил-ко

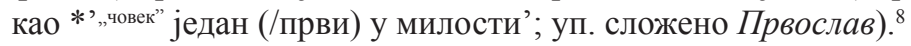

\section{Род ЛИ као речи}

3. Формативна обележја наведених ЛИ сведоче да су она обликована по моделу именица ж., м. и с. рода, што је својствено свим ЛИ на српском говорном простору (изворно словенским и несловенским - хришћанским или исламским).

3.1. Номиналне форме ЛИ која се надевају лицима женског пола садрже завршни вокал $a$, тј. углавном су обликоване као именице ж. р. $a$-парадигме (жена,

\footnotetext{
${ }^{7}$ Поред ЛИ која се разликују по акценту (Мйлија, м. : Мйлија, ж.), данас се бележе и у свему иста мушка и женска („мушко-женска”) ЛИ, што је, свакако, нова појава, настала мешањем различитих домаћих именослова (нпр. Добрица је код Срба у околине Фоче женско, а у околини Трстеника мушко ЛИ), или преузимањем страних ЛИ (уп. код Срба ново Вања, м. и ж.).

${ }^{8}$ Вероватно је да би овакво упоредно посматрање суфикса у ЛИ и именицама из других сфера именовања могло довести до прилично поузданих увида у примарне категоријалне вредности већине осталих словенских суфикса, именичких и придевских.
} 
сестра, књига - по нашим граматикама III врста), што је истовремено и формално обележје заменице она и придевских речи ж. р. (наша, лепа, добра): Мила, Милана, Милена, Милина, Милица, Милона, Миља, Миљана, Радмила; Марија, Марица, Марта, Марина, Мара, Анастазија, Ангелина, Ана; Хаснија, Мерима, Селма). Међу женским ЛИ нема имена на сугласник, тј. искључена је могућност да се она образују по моделу именица ж. р. типа ствар (по нашим граматикама IV врста, где су мати и кћu). ${ }^{9}$ Та појава указује на могућност да се при образовању женских ЛИ гледало на придевске речи и деиктике с формалним придевским обележјима, чији

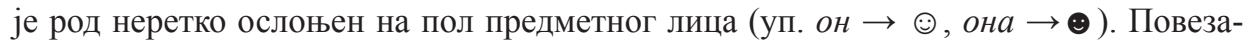
ност ЛИ и придева огледа се, поред осталог, и у томе што су многа ЛИ образована помоћу суфикса придевског порекла (уп. Мил- $а н, M u л-е н, M u љ \leftarrow{ }^{*}$ Мuл-j-) и што се ту све основе понашају „придевски” (уп. Вук, мушко ЛИ - Вук- $а$, женско ЛИ, Лабуд - Лабуд-а, Вукосав - Вукосав- $а$, Милуј - Милуј-а, Милун-Милун-а).

3.2. За разлику од формално уједначених женских ЛИ, мушка ЛИ са српског говорног простора карактерише изразита формална неуједначеност. Поред ЛИ обликованих по моделу именица м. р. (човек, мушкарац, предмет - по нашим граматикама I врста), која су, вероватно, и била и остала најбројнија (већина иначе бројних сложених ЛИ - Милорад, Радмил, Славомир, Мирослав, Миогост, Гостимил; многа изведена ЛИ - Милош, Милун, Вукан, и већина иначе ретких простих ЛИ - Вук, Паун, Голуб), постоји и мноштво ЛИ чија се номинална форма завршава вокалом а (Милија, Милојица, Малиша, Никола) као типичним обележјем именица и именских облика ж. р., односно, вокалом о/е (Радмило, Радмиле, Миљко, Миленко, Милоје) као типичним обележјем номиналних форми именица и именских облика c. p. За разлику од мушких ЛИ на $a$, која су у свему једнака именицама ж. р., ЛИ на o и е имају само номинална (не и парадигматска) обележја именица с. р.: носећи неутруму недоступну персоналну одређеност, она имају „,активни” тип акузатива (уп. Н Ми́ло/Ми́ле/ /Мйле : А Ми́ла//Мйлета, у односу на Н=A у село, поље - подврста I врсте, и дете, име - II врста).

Дакле, наспрам униформно обликованих женских ЛИ стоје мушка ЛИ разнородних формалних карактеристика, што говори да подела ЛИ на мушка и женска засигурно не почива само на роду ЛИ као речи. Иако унеколико зависне од дијалекта, варијације основних форми мушких ЛИ (нпр. Радмил/Радмило/Радмиле) и хипокористика (/ ЛИ хипокористичког порекла: Мило, Миле, Миле, Мила) указују на то да су мушка ЛИ савременог српског језика неосетљива на разлику између чланова рода као граматичке категорије, те и да род у ЛИ функционише по нарочитим принципима.

3.3. Као несумњиви формални маркери разлике 'мушко' - 'женско' у ЛИ стоји само суфиксни однос -ко : -ка (Милко - Милка), морфемски однос -ø : -а (Милан - Милана) и морфемско-суфиксални -б : -ка (Милан - Миланка). Односи у савременим ЛИ указују на могућност да је разлика 'мушко' - 'женско' у двотематским ЛИ примарно назначавана као граматички однос (Миомил-ø-Миомил-а, Братомил

\footnotetext{
${ }^{9}$ Међу женским ЛИ бележе се и ретка имена са завршним $е$, што су, у ствари, првобитни женски хипокористици у појединим српским дијалектима (уп. Доке, Јеле). У српским говорима на простору Косова и Метохије бележи се и хипокористички модел са завршним $u$ (мушки - Зоки : Зоран; и женски - Зоки : Зорана, Зорица), који засад не продире у сферу ЛИ (уп. Букумирић 2015: 225-233, 255-257).
} 
- Братомила, Миодраг - Миодрага, Драгомил-Драгомила, Радмил-Радмила, Славомил - Славомила итд.), а у једнотематским као творбени однос (Мил-ко - Мил-ка, Миленко - Миленка, Милинко - Милинка, Милунко - Милунка, Милојко - Милојка, Милованко - Милованка). До комбинованог односа (творбена и граматичка морфема) могло је доћи под утицајем семантички непрозирних хришћанских ЛИ (уп. Јован - Јованка, Јован - Јована), чије је присуство могло погодовати и упливу хипокористика у сферу ЛИ и губљењу свести о смислу разлике између ЛИ и хипокористика.

Све би то, међутим, морало тећи друкчије да су формални маркери разлике 'мушко' - 'женско' били неопходни за језик, тј. да та разлика није унапред дата или самознањем одређена, те се у језику може, али и не мора назначавати.

4. Да би се дошло до увида у начине и нивое на којима језик реагује на пол, те и схватила нужност поделе ЛИ на мушка и женска, биће корисно размотрити Ворфово представљање стања у енглеском (језик који не познаје граматички род) и Аристотелове погледе на природу разлике 'мушко' - 'женско'.

4.1. У својим истраживањима „криптотипа” (/ „прикривена класа” - испољава се тек у реакцији „сс неким споља означеним облицима”, Vorf 1979: 46-47) и „фенотипа”(/ „испољена класа” - „категорија са јасно уочљивим значењем класе и формалном ознаком или морфемом који је прати”, Vorf 1979: 50) у навахо и енглеском језику, Ворф увиђа (1979: 47) да енглески језик као криптотип носи, поред осталог, и разлику „мушко” - „женско”. Он појашњава да сва таква класирања, било да су формално испољена или неиспољена, подразумевају ,једно у дубини скривено, суптилно и тешко ухватљиво значење, које не одговара никаквој стварној речи, али које се ипак у свету лингвистичке анализе показује функционално веома важним".

Иако живи као саставни део „уобичајене свести о кл асама двају полова”), основ те „нејасне, апстрактне и неме скице поделе на полове нису речи као 'пол', 'женски', 'жене'; то је један језички однос, као нешто што је различито од језичког КАзивАњА. [...] Могло би се рећи да је оно што делује у таквом размишљању целовити притисак заменички повезаних класа речи као што су Георге, Дицк и Виллиам, или пак Јане, Суе и Бетту, а НЕ НЕки ВерБАлни поЈАм као 'мушко' или 'женско'. [...] Лингвистичку класификацију каква је род у енглеском језику, која нема испољену ознаку актуализовану заједно са речима своје класе, већ делује кроз невидљиву 'разводну таблу' структурних веза на такав начин да одређује неке друге речи које означавају ту класу”, Ворф назива (1979: 45, спац. Ј. Р.) „ПРикривенА класа, за разлику од испољене класе, каква је род у латинском" или српском језику.

Ту „нему скицу поделе на полове” Ворф анализира (1979: 46) напоредо с класама неживих тела у навахо језику, које су лингвисти, у покушају да „нешто што је суптилно опишу терминима грубог", назвали „'округли предмети' и 'дугачки предмети"” (о томе у Радић 2014, 2015). Он наглашава (1979: 43) да енглески род, као и поменуте класе у навахо језику, није ништа друго до „систем релација”, чије су ,jедине моторне реакције заменице 'он' и 'она'”. Уз у енглеском малобројне термине сродства и појмове везане за старосну доб (нпр. girl 'девојчица, девојка' : boy 'дечак, младић'), на том „систему релација” почивају сва ЛИ (Ворф 1979: 44). Иако не носе „никакав дистинктивни знак који би указивао на њихов род [= пол носиоца ЛИ], какви су у латинском '-us' и '-a'; [...] свака од ових хиљада речи има непро- 
менљиве структуралне везе које је с апсолутном тачношћу повезују било са речи 'он' или са речи 'она', што, међутим, не улази у слику испољеног понашања ако се и док се не појави посебна говорна ситуација која то захтева"(Ворф 1979: 44).

Напомена да ЛИ „неизбежно класификују” индивидуе по полу, те да употреба тих „родом повезаних” именица не зависи „од познавања било које посебне индивидуе” на коју се неко ЛИ може односити (Vorf 1979: 44), наговештава схватање да би само именовање и поособљење лица било немогуће без прикључења класи „он” (,мушко”) или класи „она” (,женско”), односно, да би без поделе људских бића у основне биолошке класе немогућа била и сама изградња персоналних идентитета. Наиме, ако је не-посредно класирање просторних ентитета на „линеарне” и „нелинеарне" основ стварања мозаичке слике одређене области и услов сналажења у простору, биће да је и не-посредно класирање људских бића на „мушко” и „женско” основ стварања персоналних идентитета и услов сналажења у друштву.

Та логика говори да разлика „мушко - женско” припада реду самознаних разлика и да у свим језицима, независно од тога познају ли род и/или личне заменице „он” и „она”, заиста делује као унапред дата „разводна табла”. Тај унапред дат однос (1) може остати формално неиспољен, како је ,у језицима без родова одређених по полу, какви су кинески или хопи” (Vorf 1979: 45); (2) може бити „минимално испољен кроз морфеме”, како је у енглеском, који као једине „моторне реакције” има заменице „он” и „она”, ${ }^{10}$ или (3) бити назначаван различитим средствима и испољаван на различитим логичким нивоима, попут стања у српском језику.

Судећи по Аристотеловим и неким савременим увидима, али и по стању у српском као језику изразито осетљивом на разлику 'мушко' - 'женско', та разлика никад не делује на највишем логичком нивоу, тј. не делује у језику као систему симболичко-семантичких јединица (Сосирово langue).

4.2. Наиме, у контексту испитивања односа између родова (у логичком смислу) и врста, Аристотел разматра и могуће питање ,зашто се жена од мушкарца не разликује по врсти, ако су мушко и женско супротни а разлика јесте супротност, тј. зашто женка и мужјак нису по врсти [подразумева се да нису ни по роду] други, иако је ова разлика по себи разлика животиње [спац. J.P.], те женско и мушко не припадају животињи ['живом створу'] као белина или црноћа већ утолико уколико је она животиња ['живи створ']" (Mem. 1058a30-1058б: 5). У одговору на ово питање, Аристотел наводи да „супротности које се налазе у одредби [а одредба је „име” бивства, тј. појам] чине разлику по врсти, а оне које су у том што је здружено с тварју не чине” (Меm. 1058б: 1-5), констатује да је 'мушко' и 'женско' здружено с тварју, због чега појмови човЕк или коњ, који као појмови постоје само уколико су одвојени од твари, не садрже ту супротност, и закључује да 'мушко' и 'женско' јесу

\footnotetext{
${ }^{10}$ Те категоријално-елементарне јединице не-посредно (не-симболички) категоришу („људско”), класираји (она ,/људско/ женско”, он „,људско/ мушко”), показују (она $\rightarrow$ ๑, он $\rightarrow$ ()) $)$ и евоцирају (она ' (-) ', он ') '). Познато је да стари европски језици (грчки, латински, старословенски) нису имали заменице типа „он” и „она”, којих нема ни у многим савременим језицима (нпр. турски и монголски). Тамо „уместо личних заменица трећег лица постоје само показне” заменице (J. Lyons, Semantics II, премa Klajn 1985: 102). И наше истраживање заменица у онтогенези указује на след показне заменице $\rightarrow$ заменице трећег лица (он, она): нпр. она (уз гест усмерен према непознатој женској особи) $\rightarrow$ Није Дана, она, Јецуа (једна од две познате женске особе) $\rightarrow$ она (в. Радић 2012: 58, 61).
} 
„особена својства животиње ['живог створа'], али не с обзиром на њено бивство, већ у њеној твари и телу" (Мет. 1058б: 20-25).

4.3. Антички увиди у однос између „твари” и одредбе (оно што је „одвојено” од твари) говоре да језик као систем симболичких јединица вероватно и не може имати семантички пар који би као своју примарну вредност носио разлику 'мушко' - 'женско'. Наше женско и мушко су, ван сваке сумње, произашли из 'жена' и 'муж' (в. ЭССЯ: *mqžbskъjb, Фасмер: муж). Етимологија нас учи да је жена континуант ие. *gřenâ, с ие. кореном „* ${ }^{\prime}$ en- 'rađati'” у основи (Skok: žena), док се за муж реконструише ие. „, “тапи-(s) или *monu-(s) 'мужчина, муж, человек', далее, возможно, к *men- 'мыслить, думать' (ЭССЯ: *mфžb). О таквом следу сведочи и „latinska inovacija femina 'koja doji > žena'" (Skok: žena), везана, дакле, за 'дојити' (доји она која је недавно родила), а не за 'женско' (лат. femininum : femina). Све ово говори да је тек назив за „остварено женско” ('која је родила' / 'која доји' $\rightarrow$ 'жена'; уп. савремену лексикографску дефиницију „1. људско биће које има способност рађања, полно супротно мушкариу”, РСЈ: жена) $)^{11}$ омогућио да се примарна (самознана, несимболичка) комплементарна разлика "женско - мушко" разложи, те и да се 'женско' и 'мушко' издвоје као поларизоване симболичко-семантичке јединице.

Да би се унапред дата разлика "мушко - женско" изразила симболички, услов je, дакле, био да се изграде појмови типа 'жена' и 'муж, мушкарац', способни да се узму сад раздвојено (као поларизовани опозити 'жена' - 'мушкарац'), сад као комплементаран пар ('жена и муж' = 'супружници'), те да раздвојивом учине разлику "мушко - женско" ( $\rightarrow$ 'мушко' - 'женско'). То би говорило да су чланови те разлике у људској свести најпре живели као недељиви полови ,једног” („љьдско биће”, 'човек'), ${ }^{12}$ а да су тек потом, кад су на њиховим основама постављене симболичке ознаке за 'жена' и 'муж', створени услови да се полови почну узимати раздвојено - да се представе симболички (мушко - женско) и почну назначавати на не-посредан (несимболички) начин. Тај след указује на могућност да је „тварна” (унапред дата) разлика „мушко - женско” најпре и изражена симболички (мушко - женско), а да се тек потом почела назначавати граматичким средствима (граматички род) и изражавати на не-посредан начин (заменице „он” и „она”). Подразумева се да појава одговарајућих симболичких јединица и могућност назначавања разлике 'мушко' - 'женско' граматичким средствима (род, именичке заменице 3. лица) не поништава примарно јединство полова, тј. не утиче на статус самознане комплементарне разлике "мушко - женско".

Изгледа да за пренос те разлике на граматичку раван није било довољно да се полови раздвоје, већ је било неопходно да се направи извесна неравнотежа између два примарно једнаковредна дела у комплементарном односу (уп. формално стабилно жена 'femina, uhor' : формално разложено муж 'maritus', муикараи 'mas'). Добра илустрација те неравнотеже је заменичка структура она // он - оно: елеменат он је у односу на она неодређен, што се огледа у могућности да они (мн. од он) обу-

${ }^{11}$ По томе се поткласа 'жена' разликује од осталих поткласа класе 'женско': баба 'старица, женско које је изгубило способност рађања', невеста 'тек удато (још неостварено) женско', девојка 'неудато женско', девојчииа 'младо, незрело женско'.

${ }^{12}$ Управо је такав осећај за однос „мушко-женско” у мишљењу и језику могао погодовати стварању античког мита о андрогинима (о томе у Радић 2010б: 125-126). 
хвати 'он и она', елеменат она је одређен (мн. оне искључује 'он'), док је елеменат оно неутралан на разлику 'он' // 'она'. По свему судећи, те неравнотеже нема само у ЛИ (ту су оба пола подједнако одређена). ${ }^{13}$

4.4. Однос пола и рода у српским ЛИ иде у прилог већ изношеним претпоставкама да је трочлана категорија рода формирана пре и независно од пола (в. нпр. Kasirer 1985: 224-226). Напред изнесени увиди говоре да се разлика "мушко - женско" тек накнадно, након што је разложена посредством симболичких јединица, могла почети уклапати у род као трочлану морфолошку категорију. Судећи по ЛИ, то уклапање је текло тако што је 'женско' добијало одРЕЂЕно формално обележје $(f)$, док је 'мушко' остајало формално неодРеъЕно $(m, f, n) .{ }^{14}$ То би, даље, указивало на могућност да се ни сам род примарно није тицао природе ствари у реалности, ${ }^{15}$ већ начина на који се предметни свет поима или „узима”, што увек подразумева На Нечем засновану разЛИКУ ТИПа оДРЕЪЕНО (/ОБЕЛЕЖЕНО) ॥ НЕОДРЕЪЕНО (/НЕОБЕЛЕЖЕНО) - НЕУТРАЛно (f $\| \mathrm{m}-\mathrm{n}$ ). То би, уједно, разумљивом чинило појаву да језиком доминира м. р., те и да су персонални апелативи већином уобличени као именице м. p. (персонална неодређеност $\rightarrow$ неодређен пол $\rightarrow$ мушки род).

5. Према оном што су класе засноване на полу као биолошкој разлици људских и свих других живих бића ('женско' - 'мушко'), феминизам поставља конструкт друштвених „родова”, а та „род” се, поред осталог, дефинише и као „друштвено-културно уобличен појам полности у људском друштву” (Jovančević 2003). Не примећује се, притом, како сам језик показује да се 'женско' (/ жена) и 'мушко' (/ мушкарац) не могу ни у ком смислу узети као „друштвени родови”, јер све што је друштвено подложно је вредновању: према човек стоји нечовек (и према људи - нељуди) јер се човек вреднује као друштвено биће (приписује му се људскост или нељудскост), док према женско и жена не постоји *неженско или *нежена (или према мушко - *немушко) из простог разлога што су и 'женско' и 'мушко' као друштвена бића исто - чОвек или НЕЧОвек (уп. *невук, *несвиња, *нехраст, па и *нечовек ако се узима биолошки). Ово, свакако, из разлога што се 'мушко' и 'женско' тиче људског тела (биолошка димензија људског бића као „лица”), а не људских јединки као чланова заједнице (особа), где се човек посматра као човек а не као „тело и твар”.

5.1. Развијен из првобитног покрета који се борио против имовинске, политичке и породично-правне дискриминације жена (Антонић 2011: 11), феминизам је еволуирао у утицајну социолошку теорију с две основне струје, познате као „родни феминизам” и ,либерални”/,индивидуалистички” феминизам (в. Антонић 2011: 9-10). Типови језичких структура су, изгледа, умногоме утицали на то који ће феминистички покрет бити инсталиран у одређеном друштву - „родни” (/ „радикални”), који у језику тражи доследну поларизацију, или „либерални”, који тражи потпуну

\footnotetext{
${ }^{13}$ И симболичке ознаке полне карактеристике људских бића (мушко - женско) су тек начелно у равнотежи, тј. тек су привидно једнаковредне: зависно од пола носиоца језичке свести, једно је увек ,по себи" одређено, а друго неодређено.

${ }^{14}$ Излажући своје увиде у појаву мешања различитих прикривених и испољених класа у језику, Ворф запажа да „možemo imati takve iskustvene razlike nakalemljene na čisto gramatičke klasifikacije, što proizvodi mešane klase kao što bi bila 'iskustvena prisutnost [= ОдРЕъЕност] plus gramatički ženski rod'” (Vorf 1979: 79).

${ }^{15}$ Пипер говори (2016: 39) о роду као „слабо семантизованој категорији” у савременим словенским језицима.
} 
неутрализацију семе 'пол'. У Србији траје већ поодмакло инсталирање радикалног феминизма (в. Антонић 2011, на више места), који најагилније делује управо на пољу језика, с почетним задатком да „родно диференциран језик” учини обавезним у медијима и образовању - доменима који ће најбрже и најшире деловати на целину језика, свест и мишљење будућих генерација. Иако је у последњих 30-ак година код нас објављено више стручних и научних прилога који оспоравају сврсисходност и ваљаност траженог језичког модела (в. Ивић 1989, Радић 2010а, 2010б, 2013, Пипер 2016), он се тоталитарним методама упорно намеће, тако да је „родно диференциран језик” превладао у јавном говору појединих наших центара, при чему сваким даном добија и све ширу законску подршку.

5.2. Доминацију мушког рода у српском језику феминисти тумаче као одраз патријархалне свести и доминације мушкараца у друштву, негирајући чињеницу да основно значење речи типа човек, професор, учитељ, филозоф, декан, говорник, посланик и сл. подразумева неутралност на пол. Они, стога, траже да се у језику спроведе доследна поларизација 'мушко' - 'женско', односно, да се по моделу фемининатива, који спонтано настају деловањем механизма именичке моције (кад се звање узима као замена за ЛИ - професорка Ивић, или само професорка $\rightarrow$ 'Милка Ивић') и аутоматски се повлаче кад тога дејства нема (нпр. кад се звање узима као звање, у функцији предикатива или атрибутива - она је професор, професор Милка Ивић), - разложе сви персонални називи (уп. маштовит „регистар” у Mijušković 2013). Тим поступком ce, фактички, поништава механизам моције рода, јер доследна „феминизација” подразумева нужност да се и у „мушке” (основне) форме таквих речи учитава податак 'мушко' (нпр. професор постаје само 'мушкарац професор'). Резултат тог поступка су две поларизоване речи истог вредносног ранга - професор и професорка. При том ce не опажа (/ не признаје се) да то подразумева фактичко деградирање речи која значи и означава (професор 'звање, занимање; лице у том звању'; професор $\rightarrow$-) / 'одређена особа мушког пола као носилац звања / занимања професор'), - у реч која само означава. Уосталом, и сам захтев да 'жена' буде „видљива у језику”, на чему феминисти упорно инсистирају, подразумева реч-етикету (ЛИ) и доследо везивање за нижи логички ниво. Ако се покаже да је тај пројекат уопште могућ, брисање разлике између професор (општепојмовна реч, способна да означи одређено лице мушког пола) и професорка (форма без опште вредности, резервисана да означава лице женског пола) условиће губљење координације и свођење персоналних апелатива на ранг ЛИ, а тиме и немогућност системске организације.

5.3. Кад су у питању ЛИ, о изостанку њихове системске организације и издвојености из језичког система уверљиво сведочи то што су током новога века, с прихватањем и укорењивањем нових монотеистичких религија, многи народи напустили целину својих традиционалних именослова и заменили их ЛИ створеним у туђим језицима и културама, а да се те промене ни у чему нису одразиле на језик као систем. Примера ради, потпуна промена именослова десила се код исламизираних говорника српског језика (део дотадашњих Срба с простора Рашке, Црне Горе, Херцеговине, Босне), чиме је њихов говор остао недирнут - на системском плану се ни у чему не разликује од говора Срба с којима су делили и деле исте дијалекте. То уверљиво сведочи да је тип поларизације (/,родне диференцијације”) својствен именословима неспојив с организацијом системског типа. 


\begin{abstract}
$* * *$
Ако језик (фp. language) чине системи међусобно испреплетаних категоријалних, симболичких и граматичких вредности, које се граде и одржавају у међусобним односима и у односима координације, онда је јасно да разлика „мушко - женско” примарно припада реду принципа који не траже језички израз. Да би добила језички израз, услов је, изгледа, да се та разика помеша с неким другим разликама које језик поставља - с неком другом семантичко-симболичком или и граматичком разликом, те и да се поларизована опозиција уклопи у привативну, што подразумева двочлано-трочлане логичке структуре тиПа оДРЕЂЕНО (/ ОБЕЛЕЖЕНО / ПОЗИТИВНО) $\|$ НЕОДРЕЪЕНО (/ НЕОБЕЛЕЖЕНО / НЕГАТИВНО) - НЕУТРАЛНО (НПр. ЖеН // мУж (/ Човек) - дете, она // он-оно, $f / l m-n$; жена // човек - човек, учитељицуа // учитељ - учИтЕљ). Кад је реч о семантичко-симболичким јединицама типа човек или учитељ, којима је доступно кретање по логичким нивоима и досезање „општег” (не-персонална или персонално неодређена вредност), ту заједно са свим другим што је ,у твари и телу" мора бити занемарен и 'пол'. Само по себи, то говори да у језику као систему симболичко-семантичких јединица (Сосирово langue) не може постојати ни 'женско', ни 'мушко', те и да се вештачки пројекат „родно диференцираног језика” понајпре може разумети као експеримент чији би успех за последицу имао разарање језика као система који нам омогућава појмовно (продуктивно) мишљене и вољно одлучивање.
\end{abstract}

\title{
Лuтература
}

Антонић С. Искушења радикалног феминизма. Моћ и границе друштвеног инжењеринга. Београд: Службени гласник, 2011.

Бошковић Р. „Развитак суфикса у јужнословенској језичкој заједници (1936).” Одабрани чланц̧и и расправе. Титоград: ЦАНУ, 1978: стр. 45-175.

Букумирић М. Ономастика изентралног Косова. Библиотека ономатолошких прилога, књ. 3. Београд: САНУ, 2015.

ЭССЯ - Этимологический словарь славянских языков (ред. О. Н. Трубачев) 1-. Москва: Наука, 1974-.

Ивић М. „Нека запажања о броју и роду у српскохрватском језику.” Јужнословенски филолог, XLV(1989): стр. 27-44.

Клајн И. Творба речи у савременом српском језику. Други део: суфиксација и конверзија. Београд, 2003.

Пипер П. „О социјалним фемининативима у српском и другим словенским језицима." Јужнословенски филолог, LXXII/3-4 (2016).

Радић J. „Појам род у граматици и логици (у светлу 'феминизације' српског језика).” Поводом 50-годишњице Филозофског факултета Универзитета у Приитини, у част проф. др Милосаву Вукићевићу (посебно издање Зборника радова). Косовска Митровица, 2010а: стр. 387-396.

Радић Ј. „Род у природи, граматици и друштву.” Гласник Етнографског института CАHУ LVIII/1 (2010б): стр. 115-130. 
Радић J. „О следу заменичких јединица у онтогенези.” Книжевност за деиу и омладину - Наука и настава. Јагодина: Факултет педагошких наука у Јагодини, 2012: стр. 57-66.

Радић Ј. „Доследна 'феминизација': испољавање свести о равноправности полова или пут у менталну деградацију.” Филолог, 8/IV (2013): стр. 25-36.

Радић J. „Из методологије трагања за примарним вредностима суфикса (Категоријални приступ: од ул-ица до учитељ-ииа).” Зборник Матице српске за филологију и лингвистику, LVII/1 (2014): стр. 151-181.

Радић J. „Суфикси -ина и -ица као опозити у географској терминологији и топонимији (У светлу категорије квантитета)." Ономатолошки прилози, XXII (2015): стр. 17-63.

РСЈ - Речник српскога језика, Матица српска, Нови Сад 2007.

Стевановић П. Речник имена. Редиговала и поговор написала Ј. Радић. Београд: Завод за уџбенике, 2014.

Фасмер М. Этмологическый словарь русского языка. Том II. Москва, 1986.

Jovančević S. Autoritarnost kao elemenat društvenog karaktera i činilac društvene interakcije polova $<$ http://www.komunikacija.org.rs/komunikacija/casopisi/fid/XXIIXXIII/d09>2003.

Kasirer E. Filozofija simboličkih oblika. Prvi deo-jezik. Novi Sad: Dnevnik, 1985.

Klajn I. O funkciji i prirodi zamenica. Beograd: Institut za srpskohrvatski jezik, 1985

Aristotel. Metafizika. Prevod, komentari i napomene Blagojević U. Slobodan. Beograd: Paideia, 2007.

Mijušković S. Registar zanimanja, zvanja i titula žena. Prilog upotrebi rodno osetljivog jezika u sferi javne komunikacije. Podgorica: Ministarstvo za ljudska i manjinska prava, 2013.

Skok P. Etimologijski rječnik hrvatskoga ili srpskoga jezika. Zagreb: JAZU, 1971-1973.

Vorf B. L. Jezik, misao i stvarnost. Beograd: Beogradski izdavačko-grafički zavod, 1979.

Jovanka J. Radić

SERBIAN PERSONAL NAMES AND THE FEMINIST APPROACH TO LANGUAGE

Summary

The paper examines the principle of polarization and the ways in which personal names in the Serbian language are organized. This primarily includes an analysis of the relationship between the sex, tentatively defined as a semantic 'female' - 'male' distinction, and gender, as a formal grammatical feature of Serbian personal names. Drawing on Whorf and relying on Aristotle, we demonstrate that the language bears the 'male - female' distinction as a relationship between two predefined complementary classes. Regardless of whether a language distinguishes the gender and regardless of the way it reacts to the sex, this distinction that is understood by itself dictates that the identity of a person be determined and classified as 'male' or 'female' at the mo- 
ment of naming. As the relationship between these classes does not allow us to coordinate and elevate personal names to a general level, they lack a systemic organization. This indirectly reflects the organizational principles of the language as a system and reveals some of the consequences of the ideologically motivated demand to apply the 'male' - 'female' distinction consistently. The paper demonstrates that the implementation of such demands put forward by the proponents of influential "gender feminism" would be devastating for the human language and thought.

Key words: onomastics, anthroponymy, personal names, 'male' - 'female' distinction, grammatical gender, gender motion, feminism. 